\title{
WHAT IS A PATENT? AND EXAMPLES IN SUZUKI PRODUCT COMPANIES FAKHRI MUSLIDAR
}

155100029

Faculty of Computer, 448757220

Fakhrimuslidar.student@umitra.ac.id

\begin{abstract}
Patent is an exclusive right granted by a State to the inventor of the findings in the field of technology, which for a certain period of time carries out its own invention or invention or gives approval to other parties to carry it out. (Republic of Indonesia Law No. 14 of 2001).

The word patent itself comes from English, which is a patent, which originally came from the word patere which means opening and also from letters patent terms, is a decree issued by an empire that gives exclusive rights to individuals and certain business actors. From the definition of the word patent itself, the patent concept actually encourages an inventor to open knowledge for the betterment of society and instead, inventor gets exclusive rights for a certain period.

Suzuki, a well-known company brand with a variety of production products that have no doubt and have been worldwide, they also pass many obstacles and obstacles that once plummeted experienced by a patent holder by this product. At the beginning, Suzuki only had a little knowledge about producing cars and motorbikes, but in the end he was optimistic that he had to learn something he did not know to make it big, and it was proven that Suzuki is so global and has made abundant profits. The amazing thing is the brilliant idea of the voters of the product patent by looking for references from something that is already well-known as a reference for the new business. Automatically, their first step in making a good motorbike \& car by imitating European-made cars is very true
\end{abstract}

Keywords: Patent, exclusive, technology, invention, and inventor. 


\section{A. INTRODUCTION}

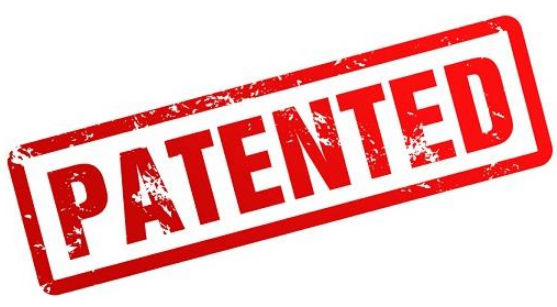

Patent is an exclusive right granted by a State to the inventor of his invention in the field of technology, which for a certain period of time carries out his own invention or invention or gives his consent to other parties to carry out it. (Republic of Indonesia Law No. 14 of 2001).

Here are 2 things related to patents:

1. Invention, invention is an Inventor idea that is poured into a specific problem solving activity in the field of technology that can be a product or process, or a product or process improvement and development.

(Republic of Indonesia Law No. 14 of 2001, Article 1, paragraph 2).

2. Inventor, Inventor is a person who alone or several people who jointly carry out ideas poured into activities that produce an invention.

(Republic of Indonesia Law No. 14 of 2001, Article 1, paragraph 3).

The word patent itself comes from English, which is a patent, which originally came from the word patere which means opening and also derived from the term letter patent, which is a decree issued by an empire that gives exclusive rights to individuals and certain business actors.

From the definition of the word patent itself, the patent concept actually encourages an inventor to open knowledge for the betterment of society and instead, inventor gets exclusive rights for a certain period.

\section{Subjects that can be patented:}

There are 3 categories of subjects that can be patented, namely: machines, processes, and items produced or encountered by 1 or more people

In Indonesia, the requirement for the findings to be patented is something that is new or has never been disclosed or discovered before, contains inventive steps (unpredictable), and can be applied in industry. The protection period for a patent is usually 20 years, while a simple patent is 10 years.

Patents cannot be extended. To ensure that the researched technology has not been patented by other parties and is worth patenting, patent documents can be traced. 
Speaking of patents, in this article I will discuss Suzuki products that are quite well known in the world of industry, especially business in the field of technological advancement. The following is the patented Suzuki logo:

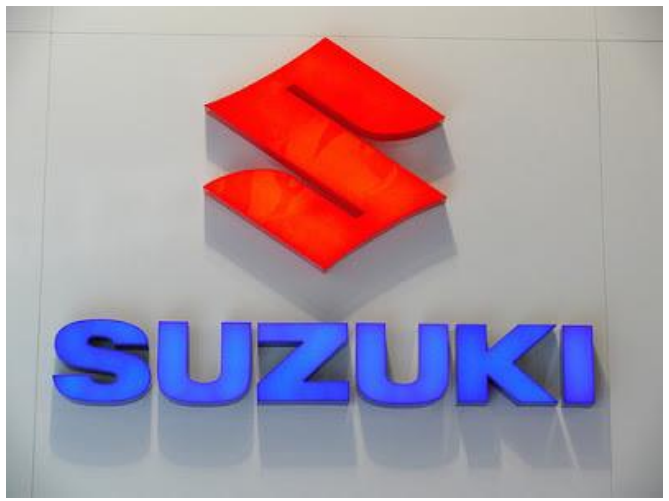

Apart from that, of course the patent will be associated with one or more figures as holders of ownership rights of the product. At this company, the name that I will associate is a great figure named Michio Suzuki.

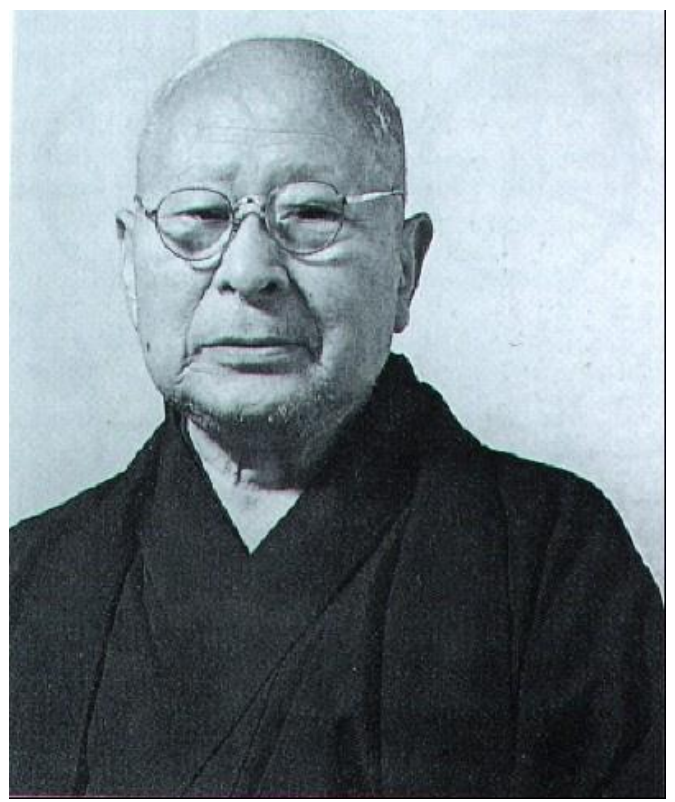

Michio Suzuki is a child of a traditional cotton farmer from Japan. Michio Suzuki was born on February 10, 1887 in Hamamatsu City, a city filled with woven fabric industry.

The beginning of Suzuki working in the World of Business \& Production began in 1909, or when Suzuki was 22 years old. In that year, at first he tried to design a wooden loom that was operated with a Pedal, and began selling his products to the area around Hamamatsu at a price of 50 Yen / Unit.

Unexpectedly, the business went well, the products were increasingly accepted by woven fabric craftsmen and were known by many people. On this basis, Suzuki later founded the Suzuki Loom Works in Tenjin Area (Now Nakajima City), Hamamatsu.

Eleven years later, after the success of looming his business in the field of weaving machines then precisely in 1920, Michio Suzuki decided to introduce his business on the stock exchange.This has to be done, because Michio Suzuki needs capital to be able to continue the latest innovations and discoveries given the rapid advances in technology in Japan, expanding their business, and meeting the growing demands of the market, especially the demand for exports to foreign countries. On the basis of this, Michio Suzuki later founded the 


\section{Suzuki Loom Manufacturing} Company, Inc. (Suzuki Jidosha Kogyo), on March 15, 1920. The company was led by 72 shareholders, each of whom provided extraordinary capital to Michio Suzuki, so that the company developed rapidly. in just 2 years.

The company is again advancing, along with its Weaving Machine Expansion to Various Countries in Southeast Asia. Unfortunately, due to the Great War with China in the late 1930s, Japan's economic conditions became very weak, and the demand for weaving machines was decreasing.

However, this did not dampen the enthusiasm of a Suzuki to create something new and needed by the wider community.

Suzuki then started its steps in the Automobile field (Wheel 4). Based on his thinking about 20,000 Japanese-imported vehicles each year, this figure has not been able to satisfy the market demand for cheap but not cheap light-class vehicles. Michio Suzuki also saw this market gap and began its first step in the Automotive Sector.

Sure enough, at that time the Suzuki research team bought an Austin Seven Car from the United Kingdom, this car was then dismantled and studied by the Suzuki team. After a few months later based on their experience making Machine Weaving Products, Suzuki has been able to make a replica of the 737 cc car made in England. That was the beginning of Suzuki's invention and was known until now with the name of the owner of the patent itself, SUZUKI. At present Suzuki has developed and already has many branches of technology products.

\section{B. CONCLUSION}

The conclusion is, basically, a patent or patent is something that exists, if it is found by an individual or more people who make it into ownership rights or the right of discovery thereof which is issued in the form of industry or business.

In accordance with the origin of the word from the patent itself, it is a patent, which originally originated from the word patere which means opening and also derived from the term letter patent, which is a decree issued by an empire that gives exclusive rights to individuals and certain business actors.

Suzuki, a well-known brand of company with a variety of production products that have no doubt and already been worldwide, has also gone through many obstacles and obstacles that once experienced a patent holder by this product. At the beginning, Suzuki only had a little knowledge about producing cars and motorbikes, 
but in the end he was optimistic that he had to learn something he did not know to make it big, and it was proven that Suzuki is so global and has made abundant profits.

The amazing thing is the brilliant idea of the voters of the product patent by looking for references from something that is already well-known as a reference for the new business. Automatically, their first step in making a good motorbike \& car by imitating Europeanmade cars is very true.

\section{ACKNOWLEDGEMENT}

University Of Indonesia

University Of Mitra Indonesia

Telkom University

University Of Mellbourne

Saitama University

\section{REFERENCE (Based ISO 690 )}

A. S. Putra And O. M. Febriani,
"Knowledge Management
Online Application In Pdam
Lampung Province," In
Prosiding International
Conference On Information
Technology And Business
(Icitb), 2018, Pp. 181-187.

[2] A. S. Putra, O. M. Febriani, And B. Bachry, "Implementasi Genetic Fuzzy System Untuk Mengidentifikasi Hasil Curian Kendaraan Bermotor Di Polda Lampung," J. Sist. Inf. Dan Manaj. Basis Data, Vol. 1, No.
1, Pp. 21-30, 2018.

[3] O. M. Febriani And A. S. Putra, "Sistem Informasi Monitoring Inventori Barang Pada Balai Riset Standardisasi Industri Bandar Lampung," J. Inform., Vol. 13, No. 1, Pp. 90-98, 2014.

[4] Putra, Arie Setya. "2018 Artikel Struktur Data, Audit Dan Jaringan Komputer." (2018).

[5] Putra, A. S. (2018, July 17). Paperplain Fundamental Create Application With Borland Delphi 7.0 University Of Mitra Indonesia. Retrieved From Osf.Io/Pbrn9.

\section{E. REFERENCE (Based APA)}

Putra, A. S., Aryanti, D. R., \& Hartati, I. (2018, November). Metode SAW (Simple Additive Weighting) sebagai Sistem Pendukung Keputusan Guru Berprestasi (Studi Kasus: SMK Global Surya). In Prosiding Seminar Nasional Darmajaya (Vol. 1, No. 1, pp. 85-97).

Sari, D. P., Febriani, O. M., \& Putra, A. S. (2018, November). Perancangan Sistem Informasi SDM Berprestasi pada SD Global Surya. In Prosiding Seminar Nasional Darmajaya (Vol. 1, No. 1, pp. 289-294).

Putra, A. S. (2018). Paperplain: Execution Fundamental Create Application With Borland Delphi 7.0 University Of Mitra Indonesia.

Putra, A. S., Sukri, H., \& Zuhri, K. Sistem Monitoring Realtime Jaringan Irigasi Desa (JIDES) Dengan Konsep Jaringan Sensor Nirkabel. IJEIS (Indonesian Journal of Electronics and 
Instrumentation Systems), 8(2), 221232.

Darmawan, A., Yuliawati, D., Marcella, O., \& Firmandala, R. (2016). Sistem Absensi dan Pelaporan Berbasis Fingerprint dan SMS Gateway. EXPLORE, 7(1).

Febriani, O. M., Wahyuni, T., \& Yusuf, S. (2017). DESIGN OF WEBSITE-BASED INFORMATION SYSTEM FOR EDOCUMENT ADMINISTRASI IN THE COMMUNITY SERVICE UNIT (A Case Study at Rajabasa District). INTERNATIONAL JOURNAL OF COMPUTERS \& TECHNOLOGY, 16(7), 7010-7020.

Febriani, O. M., \& Wahyuni, T. (2017, October). PERANCANGAN SISTEM E-DOCUMENT ADMINISTRASI LOGBOOK PENELITIAN PADA UNIT LAYANAN DI BANDAR LAMPUNG. In Prosiding Seminar Nasional Darmajaya (Vol. 1, No. 1, pp. 187-194).

Febriani, O. M., \& Permadi, A. B. (2017). Implementasi Sistem Aplikasi Data Bimbingan dan Pelanggaran Siswa pada Sekolah Menengah Atas di Lampung Tengah dengan Metode Analisis dan Desain Sistem Terdistribusi (SSAD). EXPERT, 7(1).

Febriani, O. M., \& Ambarwati, L. (2015). PERANCANGAN APLIKASI PENGOLAHAN DATA

PENJUALAN UKM KELANTING KHAS TELO DESA SIDOHARJO KECAMATAN JATI AGUNG KABUPATEN LAMPUNG
SELATAN. Jurnal Teknologi Informasi dan Bisnis Pengabdian Masyarakat Darmajaya, 1(1), 77-95.

Febriani, O. M. (2015). Rancang Bangun Aplikasi Ecommercemenggunakan Freewebstore pada UKM Kelanting di Desa Sidoharjo Lampung Selatan. Prosiding Sembistek 2014, 1(02), 446-458. 